\title{
Linguistic and extra-linguistic triggers in intrasentential codeswitches
}

Yuliya Leshchenko, Tatyana Ostapenko

Perm State National Research University, Russia

https://doi.org/10.36505/ExLing-2019/10/0032/000394

\begin{abstract}
The authors present an experimental study of bilingual intrasentential codeswitches considered in the context of the triggering hypothesis. Language shifts between two typologically distant languages with a low density of cognates - Komi-Permyak and Russian - are analyzed. The results prove that the switches are induced by several types of triggers. In the first instance, the study replicates the cognate facilitation effect (a word directly preceding or following a cognate increases the chances of a codeswitch). Secondly, it is shown that this effect depends on the direction of the codeswitch and is related to the dominancy of the languages in bilingual consciousness. Finally, the influence of certain non-cognate triggers (the divergence of surface syntactic patterns along with the congruence of their underlying structures and the extralinguistic/referential relatedness of the codeswitched words) is demonstrated.
\end{abstract}

Key words: bilingual word processing, codeswitching, triggering, cognate facilitation effect

\section{Introduction}

Current linguistics defines codeswitching as a concurrent use of two or more languages executed by a bilingual/multilingual speaker within one communicative context (Gardner-Chloros 2009). It is generally assumed that the degree of the speaker's control over language shifts can differ, so conscious and unconscious codeswitches are distinguished. Unconscious codeswitching is unintentional (not regulated by the speaker) and seems to be unmotivated. It commonly occurs in the intrasentential position: languages can be changed between clauses within a sentence or within clauses between constituents of a word phrase. The sources and reasons of unconscious codeswitching represent one of the most complicated and controversial issues in the general theory of $\mathrm{bi} /$ multilingual language processing that requires detailed investigation.

Though, at first sight, unconscious codeswitches seem to be occasional and fully unpredictable, there is a high possibility that they are governed by certain implicit psycholinguistic factors. According to M. Clyne's hypothesis, unconscious shifts between languages can be triggered by certain words (trigger words) common for both of the speaker's languages - bilingual homophones or cognates with a high degree of formal and semantic overlap (Clyne 1980).

ExLing 2019: Proceedings of $10^{\text {th }}$ International Conference of Experimental Linguistics, 25-27 September 2019, Lisbon, Portugal 
Basing on the study of taped conversations of German-English and DutchEnglish bilinguals, the author argues that "such words can cause speakers to lose their linguistic orientation and to codeswitch, either immediately after, or in anticipation" (ibid, p.401).

Further studies of the "cognate facilitation effect" (the presumption that the presence of a cognate greatly enhances the chances for a codeswitch) proved its validity for a pair of typologically related languages with a strong lexical overlap/high density of cognate words (Dutch and English) and two pairs of typologically distant languages with a weak lexical overlap (Moroccan Arabic and Dutch; Russian and English) (Broersma, de Bot 2006). Moreover, it has been hypothesized that, apart from cognate words, there may be other phenomena that can trigger a codeswitch. However, taken together, the general amount of data on triggering is scarce; much more studies of different language pairs are needed to elaborate the cognate facilitation hypothesis, to reveal some other triggering items and, overall, to prove that triggered codeswitching is a robust and general phenomenon.

\section{Experimental research: Material and methodology}

In the paper, the authors present a study of unconscious intrasentential codeswitches performed by bilingual speakers of two typologically distant languages (Komi-Permyak and Russian) in experimental settings.

At the first stage of the study we conducted a psycholinguistic experiment (a free associative test) with adult Komi-Permyak - Russian bilingual speakers (65 university students aged $17-23)$. The test included two trials with the identical stimuli list of 54 high-frequency words presented first in the Komi-Permyak language, and then in Russian. As a result, we received a considerable number of "stimulus-reaction" pairs that make up codeswitching word combinations (CWCs) formed according to the syntactic rules of the Komi-Permyak and/or Russian languages (семья- ылжыт 'large family'; чожа-быстро 'walk quickly'). At the second stage, a survey revealing the usage frequency of the received CWCs in spontaneous speech of Komi-Permyak - Russian speakers was carried out.

\section{Results and discussion}

Our study aimed at answering the following questions: Is cognate facilitation effect valid for the switches between the Komi-Permyak and Russian languages? Does this effect depend on the direction of the switch? What other factors (besides cognate words) can trigger a codeswitch?

To answer the first question, we analyzed how the presence of a cognate word in a CWC influences its overall usage frequency. The results of statistical analysis showed that the majority of the CWCs marked as habitual, regularly used by the Komi-Permyak-Russian speakers include a cognate word (either as the first, or the second constituent); the less frequent the CWCs are, the fewer 
of them contain a cognate. Thus, the cognate facilitation effect is obviously manifested in our experimental data.

Further, we examined how this effect depends on the direction of the codeswitch. For this purpose, we grouped all the high-frequency CWCs into the Komi-Permyak-Russian and Russian-Komi-Permyak ones and analyzed the position of the trigger within each CWC. Interestingly, we revealed that in Russian-Komi-Permyak CWCs the most frequent triggering type is linear triggering: the first constituent of a CWC is a cognate word (погода-бур 'nice weather'). Alternatively, the majority of the Komi-Permyak-Russian switches are evoked by reverse triggering with the cognate word as the second constituent of a CWC (кывзыны-внимательно 'listen attentively').

Presumably, this tendency can be explained by the dominance level of the two languages in the speakers' consciousness: though both are the native languages acquired from birth and used fairly often, Russian seems to dominate over Komi-Permyak for a number of reasons. Thus, it is highly probable that Russian words (words of the dominant language) have stronger intralingual connections, so that a switch to Komi-Permyak needs to be facilitated by a cognate word, as it requires certain effort on the part of the speaker. On the contrary, for Komi-Permyak words (words of the weaker language) both intraand interlingual connections can be equally strong; therefore, switching to the Russian language does not need much cognate facilitation, as it is easy enough by itself.

Finally, the analysis of the CWCs with non-cognate constituents enabled to reveal two main factors that most probably evoked a codeswitch. In the first instance, this is the divergence of Russian and Komi-Permyak syntactic patterns on the surface structure level along with the congruence of their underlying structures. As long as Komi-Permyak has a bound word order which imposes certain syntactic constraints on word collocation (e.g., noun and verb phrases can be formed only with adjectives and adverbs in preposition), the speakers often conjoin a Komi-Permyak noun or verb with a Russian adjective or adverb as this does not contradict the Russian syntactic rules.

Another important factor that induced a codeswitch turned to be the extralinguistic/referential one. The majority of non-cognate Komi-Permyak Russian CWCs referred to the academic communicative context (вовлыны -на пары 'attend lessons', кывзыны-мекцию 'listen to the lecture'), while most of the Russian-Komi-Permyak CWCs described family and friendly relationship (Аюбить-ай мамос 'love Mum'; хороший-ёрт 'good friend'). It should be noted that the triggering potential of the extra-linguistic factor has a dependent character: it can trigger a codeswitch by itself, when no other facilitating factors are present; however, when combined with the cognate facilitation effect/syntactic pattern divergence, its influence is boosted dramatically. Thus, the overwhelming majority (over 90\%) of the highest-frequency CWCs were 
132 Y. Leshchenko, T. Ostapenko

influenced by the cumulative impact of both linguistic and extra-linguistic triggers.

\section{Conclusions}

The received results demonstrate that intrasentential codeswitches common for Komi-Permyak-Russian bilingual speakers can be induced by both linguistic and extra-linguistic triggers. The study replicated the existence of the cognate facilitation effect; besides, the relatedness of this effect to the dominancy of the languages in bilingual consciousness has been shown. The influence of noncognate linguistic (divergence of the surface syntactic patterns) and extralinguistic (referential attributes of Komi-Permyak and Russian words) types of triggers on the codeswitch has also been demonstrated. Taken together, the received results contribute to a better understanding of the triggering mechanism in bilingual codeswitches.

\section{Acknowledgements}

The research is supported by the Russian Foundation for Basic Research, grant №17-29-09074 "Combined trilingualism and its influence on linguistic and cognitive activity of an individual: an integrative model".

\section{References}

Broersma, M., de Bot, K. 2006. Triggered codeswitching: A corpus-based evaluation of the original triggering hypothesis and a new alternative. Bilingualism: Language and Cognition 9(1), 1-13.

Clyne, M. 1980. Triggering and language processing. Canadian Journal of Psychology 34(4), 400-406.

Gardner-Chloros, P. 2009. Code-switching. Cambridge, Cambridge University Press. 